\title{
Some Facts about Climate, Air Temperature and Geographic Length and Water Supply in the Republic of Macedonia
}

\author{
Vesna Ambarkova ${ }^{1 *}$ and Batra Manu ${ }^{2}$ \\ ${ }^{1}$ Department of Paediatric and Preventive Dentistry, University St. Cyril and Methodius, Republic of Macedonia \\ ${ }^{2}$ Department of Public Health Dentistry, Surendera Dental College \& Research Institute, India
}

*Corresponding author: Vesna Ambarkova, PhD, MSc, DDS, Faculty of Dental Medicine, Department of Paediatric and Preventive Dentistry, University St. Cyril and Methodius, Skopje 1000, Republic of Macedonia, Tel: ++38970686333, E-mail: ambveki@yahoo.com

\begin{abstract}
The optimal amount of fluoride in drinking water is just one of the factors that positively influence the occurrence of dental caries and has an effect on the oral health of the population of the Republic of Macedonia. The correlation existing between dental fluorosis and fluorine concentration in water is based on average water consumption, a condition that depends directly from air temperature and local climate conditions. The climate in the Republic of Macedonia is characterized by the interweaving of Mediterranean and continental influences, and on very specific way the mild Mediterranean climate collide with the harsh continental climate. Mediterranean influences create a dry and hot summer, and continental influences cold and wet winter. The average annual temperature in our country is $11.5^{\circ} \mathrm{C}$. The warmest month of the year is July, with an average air temperature of $22.2^{\circ} \mathrm{C}$, while the coldest is January with an average temperature of $0.3^{\circ} \mathrm{C}$. Former Yugoslav Republic of Macedonia expand between $40^{\circ} 50^{\prime}$ and $42^{\circ} 20^{\prime}$ north geographic latitude and $20^{\circ} 27^{\prime}$ and $23^{\circ} 05^{\prime}$ east geographic length. To provide protection against dental caries, we need to determine the optimal concentration of fluoride in drinking water using the mean annual air temperature. The majority of the population in the Republic of Macedonia used is supplied by drinking water from groundwater, from carbonates springs.
\end{abstract}

\section{Keywords}

Optimal fluoride level, Macedonia, Drinking water fluoride level

\section{Introduction}

Republic of Macedonia with its 25.441 square kilometres takes the central part of Balkan Peninsula. According to the EU Nomenclature of Statistical Territorial Units (NUTS), the former Yugoslav Republic of Macedo- nia as a country is classified in the NUTS I and II and it is divided into 8 Statistical Regions (corresponding to EU Classification NUTSIII), and into 34 groups of Municipalities (equivalent to districts-corresponding to EU classification NUTS IV) and into 84 Municipalities including the city of Skopje (corresponding to EU classification NUTS V) (Table 1) [1].

The greatest achievement of dentistry achieved by these modern times is certainly the discovery of the protective capacity of fluorine against caries made in 1930. The studies conducted in this area have shown that fluoridated water, natural or by means of artificial adding (fluorination) reduces the manifestation of caries for around $40-50 \%$ in the case of deciduous teeth and $50 \%-60 \%$ in the case of permanent teeth [2-5].

The optimal amount of fluoride in drinking water is just one of the factors that positively influence the occurrence of dental caries and has an effect on the oral health of the population of the Republic of Macedonia [5].

Literature data dating back in the 1980's confirm that, on one hand, the percentage of reduction of caries rates achieved in the areas regulating fluorine up to 1 ppm in potable waters does not attain the high percentages reported in the past, and on the other hand, there is general downward movement of caries indicators in developed countries.

This phenomenon is due to the following: Due to the 
Table 1: Population in the Republic of Macedonia.

\begin{tabular}{|c|c|c|c|c|c|c|c|}
\hline \multirow[t]{2}{*}{ Territorial units } & \multicolumn{2}{|c|}{ Population (2002 census) } & \multirow[t]{2}{*}{ Density (per 2 km) } & \multicolumn{2}{|c|}{ Area (in 2 km) } & \multicolumn{2}{|c|}{ Settlements } \\
\hline & Number & $\%$ & & Number & $\%$ & Number & $\%$ \\
\hline $\begin{array}{l}\text { The former Yugoslav Republic of } \\
\text { Macedonia }\end{array}$ & 2.022 .547 & 100 & 78.6 & 25.713 & 100 & 1767 & 100 \\
\hline Pelagonia region & 238.136 & 11.8 & 50.5 & 4.719 & 18.3 & 343 & 19.4 \\
\hline Vardar region & 133.180 & 6.6 & 39.8 & 3.346 & 13.0 & 171 & 9.7 \\
\hline North-east region & 172.787 & 8.5 & 74.9 & 2.306 & 8.9 & 192 & 10,8 \\
\hline South-West region & 221.546 & 10.9 & 67.0 & 3.280 & 12.7 & 286 & 16.2 \\
\hline Skopje region & 578.144 & 28.6 & 318.0 & 1.818 & 7.0 & 142 & 8.0 \\
\hline South-East region & 171.416 & 8.5 & 62.5 & 2.741 & 10.6 & 188 & 10.6 \\
\hline Polog region & 304.125 & 15.0 & 123.4 & 2.479 & 9.6 & 184 & 10.4 \\
\hline East region & 203.213 & 10.0 & 48.5 & 4.188 & 16.3 & 261 & 14.8 \\
\hline
\end{tabular}

Source: Regions of the Republic of Macedonia 2016.

cumulative action of the fluorine, the extensive usage of other fluorine sources (mainly from fluorine containing toothpastes) has contributed to the fictive reduction of anti-caries action of fluoridated potable water [6].

Water represents the main source of fluorine for the human race. There are no waters with any fluorine concentration, but there are types of water containing different fluorine concentration which depends on a series of factors, mainly related to the geological nature [2-4].

The fluorine content in tap waters for each area is very important information for dentists, especially pediatric dentists. Since the 1960's, many countries in the world have prepared special cartographies of naturally fluoridated potable waters [2,3,7-9].

The information that different fluorine concentrations in drinking water has essential influence on the manifestation of dental caries has encouraged great challenge for researches from different part of world $[2,3,5,10]$. In our country, there is some information for some areas rich in fluorine and attracting the attention of dentist, which was due to fluorine related teeth harms-dental fluorosis [11-14].

The clinical state of first permanent molars (KEP), the fluorine content in potable waters and the hard-dental substances were examined by B. Bajraktariva in three areas in the Federative Republic of Macedonia for children aged from 5 to 8 . The examination of potable water fluorine in Skopje, Veles and Kumanovo has shown presence of low values (0.08-0.20 ppmF), which had its impact on fluorine content in hard dental substances (559-765 ppmF). Even though these fluorine values are far below the known caries-prophylactic concentrations, they produced certain differences in KEP values in examined cities which were equal to the following: $33.0 \%$-Skopje's children, $23.6 \%$-Veles' children and 19.4\%-Kumanovo's children-6\% [15].

Takeuchi and his associates [16-18] have determined enamel fluoride content in premolars extracted due to orthodontic indication, in case of examinees consuming potable water with $0.1 \mathrm{ppm}, 0.2 \mathrm{ppm}$ and $1 \mathrm{ppm}$ fluorine content. The results have shown significantly higher fluorine enamel concentrations in premolars from the examinees who have consumed water with optimal fluoride concentration. The authors of this study have concluded that, most probably, fluorides taken with the alimentation, beginning from toothpaste, oral medium and the direct tooth environment, represent important factors impacting fluoride concentration in hard dental substances.

Jankulovska, et al. has conducted physical and chemical examinations of enamel surface. These examinations were conducted of a series of 40 healthy premolars, with no fillings and no other alterations of enamel surface (hypoplasias), which were orthodontically indicated for extraction, which were divided into two groups. The first grout was composed of non-treated teeth, and the second one was included in topical fluoride treatment. The obtained average value of enamel fluoride content equalled to $684.5 \mathrm{ppm}$ in the case of non-treated group of teeth and $1366.5 \mathrm{ppm}$ in the case of treated teeth shows the increase of fluoride level in enamel substance after topical fluoride treatment $[17,18]$.

Čarchev, et al. suggests that by 1964, the toothpaste "crest" was the only toothpaste containing fluoride present on the market, and modern fluorides containing toothpastes percentage is equal to $98 \%$ out of the total number of toothpastes that can be found on the market [13].

Fluorine content in potable water is conditioned by several factors, such as the presence and the dissolvability of fluorine containing minerals, permeability of rocks and soils trough which flows the water, time of contact, temperature, $\mathrm{pH}$, as well as the presence of other elements such as calcium, aluminium and iron with which the fluorine can interact and form complex compound [2-4].

The occurrence of fluorine in drinking water varies depending on a type and composition of the soil. The geological structure of our country is very diverse and complex, build by segmental rocks created in almost all geological periods. The age of the geological formations in Macedonia extends from proterozoic period to quarter and build-up of various magmatic, sedimentary and metamorphic rocks. The layers of these rocks are 
extremely rare in its original horizontal position, more often are violated. Fluorine content in magmatic rocks is the following: Ultra-basic rocks-100 ppm, basic-400 ppm, intermediary-500 ppm, acid rocks-735 ppm.

Fluorine distribution in sedimentary rocks is the following: Silica sand-270 ppm, carbonates-330 ppm, clay-740 ppm, schists-740 ppm [2].

The exact molecular and cell mechanism of action of fluorides on caries and fluorosis has not been cleared yet. The impact of the factors such as genetics, environment, age, alimentation, sex and the influence of drugs on fluorine metabolism (biological availability, uptake and excretion) have not studied sufficiently.

The optimal fluorine level in oral environment that would minimize the manifestation of dental decay and dental fluorosis should be determined on an individual level, thus, having in mind the systematic (endogenous) uptake of fluorides by drinking water, fluoridated milk and food, as well as the influence of potential usage of local fluorides in the form of fluoridated toothpastes, fluoride gels, fluoride varnishes and fluorine tablets $[5,19]$.

Except in areas with high concentrations of fluoride, such as endemic areas in Tanzania, Kenya, India, China, the total intake of fluoride in humans is generally low, therefore fluoride is added artificially. This is done by endogenous access through the fluoridation of drinking water, salt, milk, the use of fluoride tablets or topical application (coating the teeth with fluoride agents, the use of dental pastes with fluorine). Today millions of people are covered by one or more forms of adding fluoride for their protection against tooth decay [20].

The first Guidelines on fluorides in drinking water were established in 1984 by WHO and were part of the first edition of Guidelines for drinking water quality. The World Health Organisation has determined the recommended value as a "concentration that does not cause any significant risk related to health during lifelong consumption". At that point, the recommended dose of $1.5 \mathrm{mg} / \mathrm{l}$ was determined for fluorides [21].

WHO Guidelines for drinking water quality contain the following:

"Upon determination of national standards related to fluorides or upon evaluation of possible consequences on human health coming from exposition to fluorides, it is very important to take in consideration the uptake of water by the population in question, as well as the uptake of fluorides from other sources (for example, from food, air and dental preparations). In the cases where the uptake from other sources shall approximate or shall be higher than $6 \mathrm{mg} / \mathrm{day}$, it would be more appropriate to consider the possibility for determining standards with lower concentration than the recommended value" [22]. Besides the above-mentioned, it has been suggested that: "In regions with high natural concentrations of fluorides in tap water, it might be difficult to reach the recommended value in certain circumstances only by means of available water treatment technology" [22].

However, in order to achieve optimal health, the WHO recommends lower fluorides concentrations, between 0.5 and $1 \mathrm{mg} / \mathrm{l}$ and likewise, in regions where caries rates are rather moderate or high, or regions with raising caries rates, the WHO recommends that fluorides concentration should be increased and reach this optimal concentration (World Health Organisation's Expert Commission on the Statute of Oral Health and Usage of Fluorides, 1994) [23].

The content of fluoride in water varies greatly. Its presence in water depends on several factors, such as the geology of the terrain, type of rocks, porosity and alkalinity of soil chemical and physical properties of water, $\mathrm{pH}$ value and temperature of the water, impermeability of the layer that carries water, the content of calcium ions that limiting dilution of fluorine and climate conditions $[2,3]$. The specific geological conditions that contribute to an increased concentration of fluoride is associated with volcanic activity in those areas.

\section{Climate in Republic of Macedonia}

The Republic of Macedonia, taken as a whole part can be said that has a transitional climate of continental features mostly moderate continental climate, and with certain modifications on the mountain climate.

Under natural conditions (geological composition, relief, climate, hydrography, soil, flora and fauna) make Republic of Macedonia one of the few countries in Europe with wealth of natural values. The temperate continental climate prevalent in Maleshev, Kumanovo, Skopje, Ovcepole, Polog, Pelagonija and Prespa Valleys. It is characterized by moderately wet and cold winters and moderately hot and dry summers.

The alternated Mediterranean, temperate continental and mountainous climate are basic climatic types on the territory of the Republic of Macedonia, as a result of the climatic and other natural factors.

Our country expands between $40^{\circ} 50^{\prime}$ and $42^{\circ} 20^{\prime}$ north geographic latitude and $20^{\circ} 27^{\prime}$ and $23^{\circ} 05^{\prime}$ east geographic length. That means our country is not very close to the equator, where reign to the end of time summer, nor very close to the North Pole where reign everlasting winter. Republic of Macedonia is situated approximately on the middle between them, in the north temperate thermal zone [5].

The climate in the Republic of Macedonia is characterized by the interweaving of Mediterranean and continental influences, and on very specific way the mild Mediterranean climate collide with the harsh continental climate. Mediterranean influences create a dry and hot summer, and continental influences cold and wet winter. 
The relief is as well the important factor for the climate in our country. The Kozuv, Nidje and Belasica mountains, as well and Jablanica, Desat and Korab mountains with their heights and direction of stretch prevent warm influences from the south and the west. The Skopska Crna Gora and the Shar Mountains prevent the cold continental influences from the north.

The air temperature is among the major elements of weather and climate. It depends directly on the substrate over which air is located, because the air is heated from the surface, and only a small fraction of solar radiation. Daily and annual changes in air temperature depend on several factors: the type of surface, the shape of the land, the time of year, the geographic position of the opacity of the atmosphere and more. To provide protection against dental caries, we need to determine the optimal concentration of fluoride in drinking water using the mean annual air temperature [19]. The temperature of the air in the Republic of Macedonia is affected by the relief, vicinity of the seas, vegetables and other things.

The maximum air temperature is reaches at 14 o'clock, and the minimum before the rising of the sun. The difference between minimum and maximum air temperature over 24 hours is called a daily range of air temperature. The higher geographic latitudes (toward the earth poles) reduce daily fluctuations, apart from lower latitudes, where the daily fluctuation of the temperature is higher. In terms of annual seasons, daily fluctuations of air temperature are higher in summer than in winter.

The air temperature in the country is affected by relief, distance from the sea, plants and more. The average annual temperature in our country is $11.5^{\circ} \mathrm{C}$. The warmest month of the year is July, with an average air temperature of $22.2^{\circ} \mathrm{C}$, while the coldest month is January with an average temperature of $0.3^{\circ} \mathrm{C}$. The Demir Kapija city had the highest air temperature measured of $44.5^{\circ} \mathrm{C}$, and the Berovo city the lowest one of $-3.5^{\circ} \mathrm{C}$. In Macedonia, there are frosty days with air temperature under $0{ }^{\circ} \mathrm{C}$. Southwest parts of the country have fewer frosty days in comparison with that from the north.

The correlation existing between dental fluorosis and fluorine concentration in water is based on average water consumption, a condition that depends directly from air temperature and local climate conditions [24,25].

Under natural conditions (geological composition, relief, climate, hydrography, soil, flora and fauna) make it one of the few countries in Europe with wealth of natural values. The outside temperature or the average daily consumption of water is one of the most important factors that determine the intake of fluoride in the body.

As a result of the geographic position and topography, the Republic of Macedonia is at the crossroads of continental and Mediterranean climates. Water regime was influenced by temperatures, rainfall, atmospheric pressure, wind and moisture vary significantly. Cold periods are short (winter), while dry and hot periods predominate (summer-autumn). Throughout the country the rainfalls are irregular, sporadic and in small quantity and with average annual precipitation of $733 \mathrm{~mm}$.

\section{Terrain}

In terms of terrain Macedonia is predominantly mountainous country. About $75 \%$ of its territory has mountains. The terrain in Macedonia is composed of hills, low, medium and high mountains, plateaus, valleys, river valleys and other terrain forms. The current terrain is created under the influence of internal and external forces through a long period that lasted millions of years. Internal forces cause movements of the Earth's crust and are called tectonic movements. Under the influence of these movements some parts of the Earth's crust lifted and descending or horizontal change places. Many millions of years ago this territory was covered with water from the great sea. Later powerful tectonic movements raised the bottom of the sea and create land. It was the Rhodope land-oldest in our country. Tectonic movements were accompanied by the occurrence of earthquakes and activated volcanoes. The consequence of these movements is created volcanic cones on the areas around Kratovo and Radovish cities and also on Kozuf Mountain. External forces such as sun, wind, precipitation, glaciers and other relief have changed and developed smaller relief forms.

\section{Rainfall}

Despite the air temperature rainfalls are also very important climatic element. From the regular arrangement of rainfall during the year depends on the survival of plant life and economic development of our country. Precipitation depends on crops, especially in areas where there is no irrigation system. The schedule of rainfall in the country has been uneven in seasons, the most rain in spring and least in summer-autumn period, the distribution is uneven and regions, a lot of rain in the western part of the country, at least in the east and partly central part (on average Vardar Valley). The average annual rainfall in the country is $680 \mathrm{~mm}$. In our country the least rainfall in the vicinity of settlement Gradsko, about $400 \mathrm{~mm}$. Rain water has a decisive importance at least in those areas whose waters do not come through the tanks from the mountains. When there is little precipitation, the concentration of fluoride in the water increases. And again, in years characterized by high rainfall, we expect the concentration of fluoride in a period of stabilization, start to decline indicating a greater dilution of shallow groundwater [19].

Fluorine uptake is increasing proportionally with the increasing of the content of fluorine in water, as well as with air temperature in the area, since summer temperatures are higher than winter temperatures $[19,24]$. Drinking-water is more often the largest single part to 
daily fluoride intake [25]. For a given individual, fluoride exposure via drinking-water is determined by the fluoride content in the drinking water and the daily water consumption. More recently national figures can be obtained or computed from various sources of environmental and water supply statistics such as World Bank [26] and World Resources Institute [27]. However, national consumption figures, especially for developing countries, may be of limited use for this purpose because there are likely to be major differences between urban and rural communities using wells and boreholes with hand pumps while people from urban area more often use bottled water and other soft drinks.

For a given individual, water consumption increases with air temperature, humidity, fitness exercise and our state of health, and is modified by other factors including diet. It is common that a country closer to the Equator, the higher will be our water consumption.

Before the introduction of any method of endogen fluoridation, it is necessary to be familiar with the following parameters:

- The content of fluorides in the springs of drinking water in winter and summer months. This examination should become a routine activity.

Table 2: Recommended amounts of fluoride in drinking water depending on climate.

\begin{tabular}{|l|l|l|l|}
\hline $\begin{array}{l}\text { Average annual } \\
\text { temperature }\left({ }^{\circ} \mathrm{C}\right)\end{array}$ & \multicolumn{3}{|l|}{ Fluorides concentration $(\mathrm{ppm})$} \\
\hline $10-12$ & Minimal & Optimal & Maximal \\
\hline $12-14.5$ & 0.9 & 1.2 & 1.7 \\
\hline $14.6-17.5$ & 0.8 & 1.1 & 1.5 \\
\hline $17.6-21.4$ & 0.8 & 1.0 & 1.3 \\
\hline $21.5-26.2$ & 0.7 & 0.9 & 1.2 \\
\hline $26.3-32.5$ & 0.7 & 0.8 & 1.1 \\
\hline
\end{tabular}

Source: Voinovic J., Tatic E., Andelic P., Pintaric J. Preventive program in dentistry. Scientific book, Beograd, 1990 [26].

Table 3: Main meteorological stations in the Republic of Macedonia.

\begin{tabular}{|l|l|l|l|}
\hline Region & $\begin{array}{l}\text { Meteorological } \\
\text { Station }\end{array}$ & $\begin{array}{l}\text { Average } \\
\text { annual } \\
\text { temperature } \\
\left({ }^{\circ} \mathrm{C}\right)\end{array}$ & $\begin{array}{l}\text { Optimal } \\
\text { fluorides } \\
\text { concentration } \\
(\mathrm{ppm})\end{array}$ \\
\hline Eastern & Berovo & 15.4 & 1.0 \\
\cline { 2 - 4 } & Stip & 18.3 & 0.9 \\
\hline Vardar & Demir Kapija & 19.3 & 0.9 \\
\hline South-eastern & Gevgelija & 20.6 & 0.9 \\
\cline { 2 - 4 } & Strumica & 19.0 & 0.9 \\
\hline
\end{tabular}

Source: web site of the Hydro meteorological Service www. meteo.gov.mk [27].
- The prevalence of dental caries.

- The prevalence of fluorosis and hypoplastic teeth alterations and

- The total quantity of the daily consumed fluorides. Their determination in food and other sources except the drinking water is a very complex and often unfulfilled intervention.

- The level of daily consuming of fluorides for the whole population, most practically and with sufficient degree of precision is specified by analyzing the urine fluorides. At the same time, it is necessary to identify the urine fluorides from several samples from the same person during the day, in order to achieve greater precision with the real level of fluorides in the plasma.

Optimal concentration of the water supply network depends on the naturally existing fluorides and the average annual maximal daily temperature. The average daily temperature is also important parameter, which is in direct way determines by the average amount of liquids that are consumed by people's body [5].

It is recognized that in areas with temperate climates, "optimal" amount of fluoride is $1 \mathrm{mg} / \mathrm{L}$. On the base of that, Table 2 have been prepared which include the proposed highest, lowest and optimal values for different average temperatures and the followed optimal fluorine concentrations in drinking water are recommended: In our country 35 meteorological stations exist. In the following Table 3 are presented five of them, which belong to certain regions.

If the water has $0.7 \mathrm{ppm}$ fluorides implementation of fluoridation is not necessary nor any other endogen method.

During the whole year, in all months the temperature of air is declined with the increase of the geographic latitude (Table 4).

The temperature of the air in winter declines less fast from the coastal parts towards the interior of the continent than it increases in summer. This is due to the enlarged amplitudes of the temperatures of the air.

The outside temperature or the average daily consumption of water is one of the most important factors that determine the intake of fluoride in the body.

In the Republic of Macedonia there is a possibility in all seasons, along the Vardar river to transport cold air masses from the European continent, as well as to occur wet and warm air masses from the Mediterranean.

Table 4: Change of the air temperature with the geographic length.

\begin{tabular}{|l|l|l|l|l|}
\hline Region & Meteorological Station & $\begin{array}{l}\text { Average annual } \\
\text { temperature }\left({ }^{\circ} \mathrm{C}\right)\end{array}$ & Geographic latitude & Geographic length \\
\hline South-eastern & Gevgelija & 20.6 & $\varphi=41^{\circ} 09^{\prime}$ & $\lambda=22^{\circ} 30^{\prime}$ \\
\hline Vardar & Demir Kapija & 19.3 & $\varphi=41^{\circ} 25^{\prime}$ & $\lambda=22^{\circ} 15^{\prime}$ \\
\hline Eastern & Stip & 18.3 & $\varphi=41^{\circ} 54^{\prime}$ & $\lambda=22^{\circ} 11^{\prime}$ \\
\hline
\end{tabular}


At that, the worst combinations of the climate happen drought and hot summers and wet and cold winters. It is the characteristic of the climate in the territory of the Republic of Macedonia.

The role of the Ministry of health, through the Republic Institute for health protection in the capital of country Skopje, is to monitor the quality of drinking water from new-sources, and Regional [28,32] institutes for health protection have the duty to monitor water quality during the whole year according to the Preventative Health Programme.

\section{Water Supply in the Republic of Macedonia}

According to the number of inhabitants and the type of source, most of the population of the country now is supplied by drinking water from groundwater, from carbonates springs (Skopje, Tetovo, Gostivar, Debar, Struga, Ohrid, Prilep, Kicevo, etc.) and on second place is population from several cities (Bitola, Kumanovo, Strumica, Veles, Vinica, Ss.Nikole, etc.) water supplied from surface water, and on third place are settlements that use groundwater foundation (Stip, Kocani, Gevgelija, Delcevo, Radovis, etc.). Very small number of people from villages of Dry Mountain used rainwater supplies $[29,33]$.

\section{Water Supply in Vardar}

Vardar region, according to the census of 2002, there are 154,535 people or $7.5 \%$ of the total population of the country. In this region, water is carried out by public communal workplace "Boshava" - Demir Капија, public communal utility "Komunalec" - Kavadarci, public communal utility "Komunalec" - Negotino, public communal utility "Komunalec" - Gradsko and public communal utility "Derven" - Veles. Public communal utility "Komunalec" - Kavadarci water supply settlements: Kavadarci Glisic, Marena, Vatasa Sopot Begnishte, Trstenik, Shivec, Vozarci, Resava Garnikovo, Bojanchishte, Kumanichevo, Konopishte, Dolna Boshava, Krnjevo and Stragovo.

\section{Water Supply in Eastern Region}

In the East region, according to the census of 2002, there are 181,858 people or $9 \%$ of the total population of the country. The supply of water from public water supply systems is satisfactory. In this region, water is carried out by public communal utility "Service" - Berovo, public communal utility "Bregalnica" - Delcevo, public communal utility "Water" - Kocani, public communal utility "Ilinden" - Probistip, public communal utility "Edinstvo-Unity" - Sveti Nikole, public communal utility "Kamena Reka - Stone River" - M Kamenica, public communal utility "Komunalno" - Pehcevo and public communal utility "Isar" - Stip.

The region is divided into 11 municipalities (Vinica and Delchevo, Zrnovci, Karbinci Kocani, Makedonska Kamenica Probishtip, Cesinovo-Stip). That urbanization is divided into 217 settlements, 209 of which are rural settlements. The region has almost four times less population growth than population growth in the country. The population density is 51 inhabitants $/ \mathrm{km}^{2}$. However, due to the permanent process of depopulation, the number of abandoned villages, villages with 100 inhabitants and villages with very high index of aging. This condition leads to a concentration of about $66 \%$ of the population in urban areas. Of particular importance are the most mineral springs and thermal waters Vinicko (Istibanja) and Stip (Kezhovica) [1].

From the water resources is paramount Bregalnica river where there are two large reservoirs "Kalimanci" and "Kocani Lake". Eastern region has no other major water resources so in the future needs of water supply and irrigation should be addressed by raising new reservoirs on Bregalnica river and other rivers (such as, eg Zletovica river). From the Public Utility Enterprise "Vodovod" Kocani, near the Kocani city are water supplied people from Kocani city and rural villages Orizari Pribachevo, Grdovci, Gorni and Dolni, Mojanci, Trkanje and Beli-White.

\section{Water Supply in Southeast Region}

In the Southeast region, according to the census of 2002 , there are 171,416 citizens or $8: 47 \%$ of the total population of the country. In this region, water is carried out by public communal utility: Bogdanci utilities, public communal utility "Communal Service" - Valandovo, public communal utility "Komunalec" - Gevgelija, public communal utility "Komunalec" - Polin - Star Dojran, public communal utility "Progress" - Radovish, public communal utility "Komunalec" - Strumica.

Geological maps of the places where we found optimal and higher concentrations in drinking water. Does the natural waters contain greater or smaller amounts of dissolved substances depends on the land, through which the water flow? The thermal and mineral springs in one area do not occur randomly, but occur due to special geological conditions. They are the result of geological events that occurred in the immediate or distant geological past periods. These hot springs in those areas are results of the major breakdowns in the Earth's crust creating deep cracks along which water can flow from great depth to reach the surface, or along which pierce the scalding magma to pour through volcanism or keep somewhere near the surface and warm groundwater around her.

Fluoride is a natural component in most water resources. He is present in the surface, more in groundwater and in most geothermal and mineral waters [30,34]. The concentration of fluoride depends on the geology of the terrain especially like rocks. As minerals containing fluoride are: apatite, fluorapatite, fluorite, hornblende and biotite. As a result, spending on the rocks containing such elements and infiltration of rainfall comes to increase the concentration of fluoride in groundwater. 


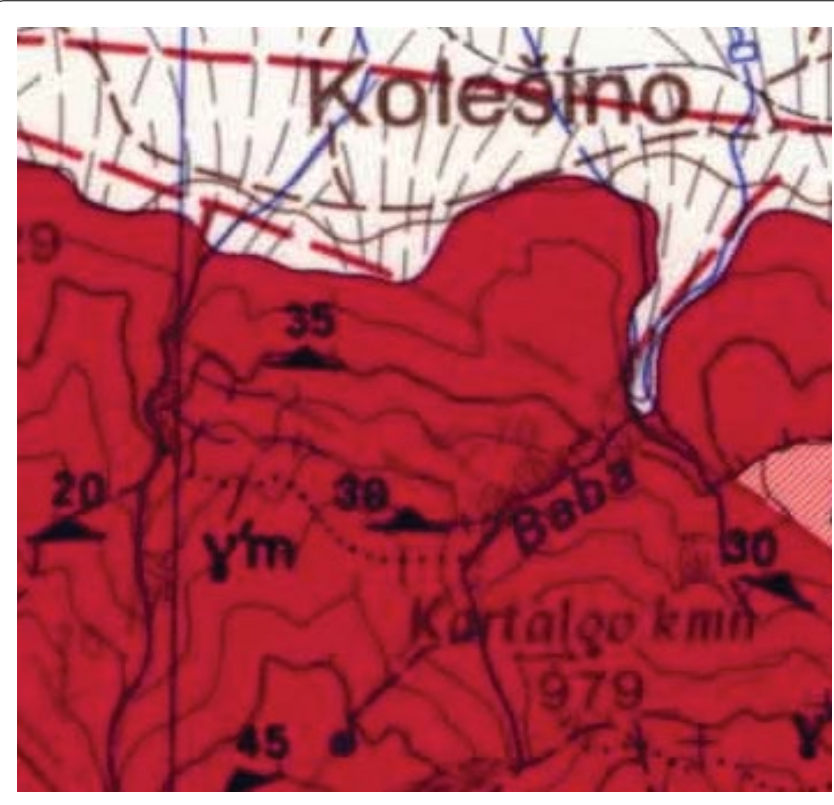

Figure 1: Geological map of the place Kolesino.

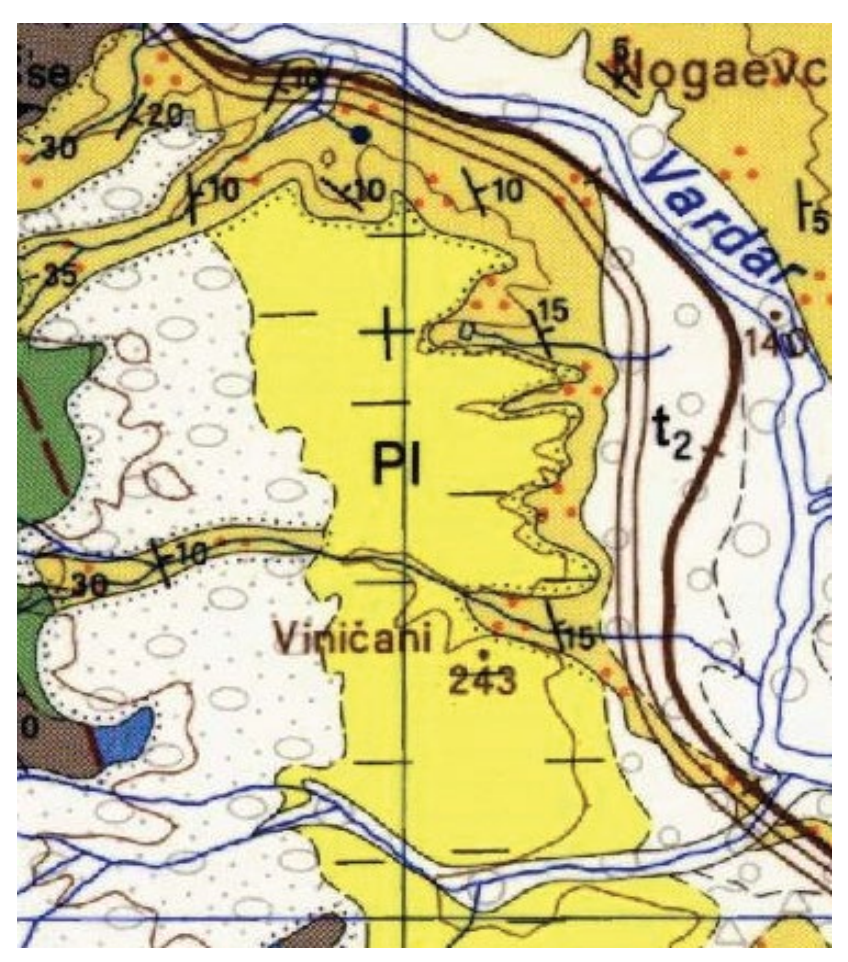

Figure 2: Geological map of the place Vinichani.

The increased concentration of fluoride in surface waters may be a result of human activity in agriculture [31,35].

The increased concentration of fluoride from the drinking water in Stip, Kolesino (Figure 1) and Vinichani (Figure 2) is due to the geology of the terrain. This space is represented by granites rocks with mineral composition: quartz, potassic feldspars, plagioclase, mica (muscovite and biotite), hornblende and augite. From accessory minerals occur: zircon, apatite, magnetite, rutile, tourmaline and others [19].

On the territory of the country are reached or oppose different mountain systems, different geological and tectonic units, each of which has some special characteristic, composition, structure, and its geological history. They acted in such a different way that condition the appearance of thermal and mineral waters. In one area, thermal and mineral waters are in abundance, and in others are almost gone, or sources are concentrated only in certain parts of the country or almost gone, or show geological features and independence to other parts of unit where they belonged. Geological structure and geological events that took place were such that our country, generally, is very rich in thermal and mineral waters. Each thermal source has its specific features, its own special mechanism of underground water movement.

\section{Related Legislation to Water}

When setting up the national standards/legislation for the content of the fluorine in the drinking water one should always have in mind how much content of fluorine is going to be consumed through the drinking water, tap or bottled tea, coffee as well as through the other sources (food, toothpastes, etc.), as well as to take into consideration climatic factors. According to the recommendations of the WHO (Guidelines for drinking-water quality Fourth Edition, 2011), as well as according to the existing regulation (Regulation for the safety of water, Official Gazette No 46/08), the content of fluorine in the drinking water has to be up to $1.5 \mathrm{mg} / \mathrm{l}$.

The protective role of the fluorine in the drinking water against the appearance of dental caries is most evident when the fluorine concentrations are from 0.8 to $1.2 \mathrm{mg} / \mathrm{l}$.

The appearance of the fluorine in the drinking water varies from the type/structure of the soil. In general, the drinking water in the Republic of Macedonia is poor with fluorine that is in correlation with the frequent appearance of caries among our population.

According to the recommendation of WHO in the Guidebook "Fluorine in drinking water" from 2011, based on many studies, it is said that daily consummation of fluorine varies from one region to another.

However, assessment has been made that says that the total daily consummation of fluorine in the mild climate regions where fluoridation of the water hasn't been carried out has to be $0.6 \mathrm{mg} /$ day for adults and $2 \mathrm{mg} /$ day in the regions where water fluoridation was carried out.

Definitely, it is obvious that a total daily intake of fluorine of $14 \mathrm{mg}$ per day leads to negative effects on the skeletal system, while a total daily absorbs ion larger than $6 \mathrm{mg}$ per day leads to increased risk of appearance of these negative health effects.

As our country is going to be a member of the EU, it is obliged to determine the values of a set of microbiological parameters and of chemical compounds, among 
which is the fluorine, within the great program of the control of the water quality, which is used by people, the water from the rivers and the lakes.

Actually, European Union countries develop their own regulations about the quality of drinking water based on the European directive for water quality from 1980. This directive provides permissible concentrations for many substances, among which is fluorine. This directive doesn't order nor prohibit the fluoridation of water, but it only demands the concentration of fluorine in drinking water not to pass over maximal allowable concentration.

In 2006 the European Commission adopted a regulation with the aim to harmonize divergent national views which refer to addition of vitamins, minerals and other substances in the food. Fluorine is included as a mineral which may be added in the food in form of sodium fluoride and potassium fluoride.
In the Progress Report 2016 for the Republic of Macedonia, prepared by the Commission of the EU it is stated that some progress has been made in the field of water quality. The new Law on setting prices on water services was adopted in January 2016. The monitoring system has improved but still lacks sufficient coverage and data collection. The first annual report on water quality and quantity was submitted to the European Environment Agency. The new Law on water has not yet been adopted by parliament. The new Law for water came in to force. The monitoring system was improved (upgraded), but there is still insufficient scope of work and collecting of data. The preparation of specific implementation plans for the Urban Waste Water Treatment and Drinking Water Directives is under way. New infrastructure is being constructed and existing infrastructure is being upgraded, although national funding is in-

Table 5: Chronological representation of the proposals from the official services (subjects, institutions) with respect to determination of the optimal concentration and avoidance of harmful concentration of fluorine in water.

\begin{tabular}{|c|c|c|c|c|}
\hline \multicolumn{2}{|c|}{ Institutions } & Proposed Cf mgF/l & $\begin{array}{l}\text { Average annual value } \\
\text { of maximal daily } \\
\text { temperature }\end{array}$ & Remarks about proposed values \\
\hline \multirow{2}{*}{$\begin{array}{l}\text { Guidebook 1962, } \\
\text { US Pub }\end{array}$} & \multirow{7}{*}{$\begin{array}{l}\text { Optimal } \\
\text { concentration }\end{array}$} & 1.2 & $10.0-12.0$ & \multirow{3}{*}{$\begin{array}{l}\text { Prevention of dental caries: provide } \\
\text { Risk of dental caries: }\end{array}$} \\
\hline & & 1.1 & 12.1-14.6 & \\
\hline \multirow{2}{*}{ Health service } & & 1.0 & $14.7-17.6$ & \\
\hline & & 0.9 & $17.7-21.4$ & \multirow{4}{*}{$\begin{array}{l}\text { - } \quad \text { Mild grade } \\
\text { - } \quad \text { Inconsiderable sensitive } \\
\text { problem }\end{array}$} \\
\hline & & 0.8 & $21.5-26.2$ & \\
\hline $\begin{array}{l}\text { Healthy People } \\
2010\end{array}$ & & & & \\
\hline $\begin{array}{l}\text { US Health and } \\
\text { Human services, } \\
2000\end{array}$ & & 0.7 & 26.3-32.5 & \\
\hline \multirow{2}{*}{\multicolumn{2}{|c|}{$\begin{array}{l}\text { WHO Internationa } \\
\text { water Guidelines }\end{array}$}} & $0.9-1.7$ & $10-12$ & \multirow{2}{*}{$\begin{array}{l}\text { Borders are determining in } \\
\text { compliance with the local } \\
\text { temperature of the air }\end{array}$} \\
\hline & & $0.6-0.8$ & 26.3-32.6 & \\
\hline \multicolumn{2}{|c|}{1980} & Max. 1.5 & $8-12$ & \multirow{2}{*}{$\begin{array}{l}\text { Borders are determining in } \\
\text { compliance with the local } \\
\text { temperature of the air }\end{array}$} \\
\hline \multicolumn{2}{|c|}{$\begin{array}{l}\text { Decree 80/778/EOC (Equal Opportunities } \\
\text { Commission) }\end{array}$} & Max. 0.7 & $25-30$ & \\
\hline \multicolumn{2}{|c|}{$1984 \& 1993$} & & & $\begin{array}{l}\text { Borders are establishing by the local } \\
\text { conditions: }\end{array}$ \\
\hline \multicolumn{2}{|c|}{$\begin{array}{l}\text { WHO International Standards for drinking } \\
\text { water Guidelines }\end{array}$} & Max. 1.5 & $10-12$ & $\begin{array}{ll}\text { - } & \text { Climate } \\
\text { - } & \text { Consumption of water }\end{array}$ \\
\hline \multicolumn{2}{|c|}{1994} & Max. 1.0 & Cold climate & \\
\hline \multicolumn{2}{|c|}{$\begin{array}{l}\text { WHO expert Committee on Oral Health\& } \\
\text { Fluoride use }\end{array}$} & Max. 0.5 & $\begin{array}{l}\text { Tropical and } \\
\text { subtropical climate }\end{array}$ & $\begin{array}{l}\text { - } \quad \text { Climate } \\
\text { - } \quad \text { Consumption of water } \\
\text { - Other sources of fluorine }\end{array}$ \\
\hline $\begin{array}{l}2 \\
\text { Council of Europe } \\
\text { Directions 98/83/Eu } \\
\text { Offical Journal of th }\end{array}$ & $\begin{array}{l}\text { opean Community } \\
\text { European Union }\end{array}$ & Max. 1.5 & $\begin{array}{l}\text { There isn't report } \\
\text { about the temperature } \\
\text { of the air }\end{array}$ & $\begin{array}{l}\text { Member States of the European } \\
\text { Union of the European Union } \\
\text { determine their own optimal value of } \\
\text { fluorine }\end{array}$ \\
\hline \multicolumn{2}{|c|}{2003} & Max. 1.5 & $\begin{array}{l}\text { There isn't report } \\
\text { about the temperature } \\
\text { of the air }\end{array}$ & $\begin{array}{l}\text { National standards are nominating in } \\
\text { proportion to: } \\
\text { - Water consumption } \\
\text { - } \quad \text { Fluorine intake from other sources }\end{array}$ \\
\hline
\end{tabular}

Despite WHO standards, contamination of water resources whether by naturally occurring phenomena or chemical wastes due to urbanization is one of the major ecological concerns in the world today [40]. 
sufficient. Also, administrative capacities are insufficient to implement all measures required under water-related directives. Some investments were made for project preparation and implementation of small infrastructure projects. The substantial investments required for compliance with the acquis have not yet been planned. Preparations in the area of water quality are moderately advanced, more efforts are needed on water quality, industrial pollution and risk management, chemicals and climate change [32,36]. force:

The following laws governing the water sector are in

- Law on Environment No. 53/05 of the Official Gazette and amendments No. 81/05 and 24/07 of the Official Gazette [33,37].

- Law on Waters No. (4/98, 19/00, 87/08, 6/09, 161/09, $83 / 10,51 / 11,44 / 12,23 / 13,163 / 13)$ of the Official Gazette $[34,38]$.

- Law on Water Management Enterprises No. 85/03 of the Official Gazette [35,39].

- Law on Drinking Water Supply and Urban Wastewater Drainage No. 68/04 of the Official Gazette [36,40].

- Drinking water is very important for our life and its quality will affect our health and quality of life, no matter whether water is bottled or tap $[37,41]$.

Regarding the contents of fluorine in the natural mineral/spring water imported or from domestic production, the contents of fluorine ranges between 0.035 and $2.220 \mathrm{ppmF}$.

According the Regulation for a special request for the safety of natural mineral water (Offical Gazette of the Republic of Macedonia No 32/06) article 14 states that if the natural mineral water contains more than 1 $\mathrm{mg} / \mathrm{l}$, it should be marked next to the name of the product or to another remarkable place "contains fluorides" $[38,42]$. If the natural mineral water contains more than $1.5 \mathrm{mg} / \mathrm{l}$ fluorides, it has to be marked that the product is not suitable for regular/continuous use for infants and children under 7-year-old.

According to evidence and analysis that are undertake by the Institute for Public Health, on the domestic natural mineral water, only Kozuvcanka (1.046 mg/l), Vizijana (1.086 $\mathrm{mg} / \mathrm{l})$ and Dobra Voda-Good Water $(0.810 \mathrm{mg} / \mathrm{l})$ contain larger amounts of fluorine that are in the limits of the recommended values from the WHO and our legal regulation. The natural mineral water with low/and very low contents of fluorine are Gorska (0.084 $\mathrm{mg} / \mathrm{l}$ ), Aqua and Kokino (for both $0.340 \mathrm{mg} / \mathrm{l}$ ) and might be consumed by the wider population, including children $[39,43]$.

The various experts from the WHO, re-examined all the available epidemiological data about dental fluorosis, dental caries and climatic conditions, which re- sulted in the preparation of many guidelines showed in chronological order on the Table 5.

It is necessary for professionals in the area of dentistry to cooperate closely with public health workers and engineers working in the area of water supply in order to be sure that consumers get good quality water containing corresponding fluorides content.

\section{Funding}

No external funding was available for this study.

\section{Statement of Conflict of Interest}

The authors declare no conflict of interest.

\section{References}

1. Regions of the Republic of Macedonia (2016) Regional yearbook. State Statistical Office.

2. V Ambarkova, V Topitsoglou, S Iljovska, M Jankulovska, M Pavlevska (2007) Fluorine Content of Drinking Water in Relation to the Geological-Petrographical Formations From FYROM. Balkan J Stomatol 11: 163-166.

3. Ambarkova V, Topitsoglou V, lljovska S, Carcev M (2005) Natural fluoridated drinking water from the Republic of Macedonia. Macedonian Stomatological Review 29: 177-182.

4. Fejerskov O, Ekstrand J, Burt A (1996) Fluoride in Dentistry. ( $2^{\text {nd }}$ edn), Munksgaard, Copenhagen, Denmark's.

5. Ambarkova V, Jankulovska M, Kocubovski M, Memeti S, Guguvcevski L (2016) Determining the optimal concentration of fluoride in drinking water from the Republic of Macedonia. J Interdiscipl Med Dent Sci 4: 199.

6. Murray JJ, Rugg-Gunn AJ, Jenkins GN (1991) Fluorides in caries prevention. ( $3^{\text {rd }}$ edn), Butterworth-Heinemann, Oxford, England, UK, 57-73.

7. Komatina MM (2001) Medical Geology. Tellur, Beograd, 56.

8. Topitsoglou V, Liatsa TH, Tsolaki A (1995) Naturally fluoridated drinking waters at the prefecture of Thessaloniki, Greece. STOMA 23: 15-22.

9. Sebastian ST, Soman RR, Sunitha S (2016) Prevalence of dental fluorosis among primary school children in association with different water fluoride levels in Mysore district, Karnataka. Indian J Dent Res 27: 151-154.

10. Akhavan G, Dobaradaran S, Borazjani JM (2016) Data on fluoride concentration level in villages of Asara (Alborz, Iran) and daily fluoride intake based on drinking water consumption. Data Brief 9: 625-628.

11. Zhang LE, Huang D, Yang J, Wei X, Qin J, et al. (2017) Probabilistic risk assessment of Chinese residents' exposure to fluoride in improved drinking water in endemic fluorosis areas. Environ Pollut 222: 118-125.

12. Goodarzi F, Mahvi AH, Hosseini M, Nedjat S, Nodehi RN, et al. (2016) The prevalence of dental fluorosis and exposure to fluoride in drinking water: A systematic review. J Dent Res Dent Clin Dent Prospect 10: 127-135.

13. Carcev M (2006) Preventive Dentistry. Faculty of dentistry, University Ss. Cyril \& Methodius-Skopje.

14. Gorgev D (1990) Fluorine in drinking water and some aspects of its impact on the health of people in the territory of the Federal Republic of Macedonia (doctoral dissertation). Skopje, Macedonia, Faculty of Medicine. 
15. Bajraktarova B, Neceva Lj, Mirceva M, Cundeva K, Doceva $\mathrm{V}$, et al. (1990) Clinical condition of the first permanent molars (DMF) and the content of fluoride in drinking water and hard dental substances. Maced Stomatol Review 14: 66-70.

16. Takeuchi K, Nakagaki H, Toyama $\mathrm{Y}$, Kimata N, Ito $\mathrm{F}$, et al. (1996) Fluoride Concentration and Distribution in Premolars of Children from Low and Optimal Fluoride Areas. Caries Res 30: 76-82.

17. Jankulovska M (2000) Fluoride concentration in oral fluid before and after topical fluoride treatment. (doctoral dissertation), Skopje, Macedonia, Faculty of dentistry.

18. Jankulovska M (2006) Fluoride in oral fluid in the prevention of dental caries. -"Grafotisok"-Skopje.

19. Ambarkova V (2015) Comparative study between oral health and natural fluorinated drinking water in certain regions of the Republic of Macedonia (doctoral dissertation). Skopje, Macedonia, Faculty of dentistry, University Ss. Cyril \& Methodius. (in Macedonian).

20. American Water Works Association (AWWA) (2016) Water fluoridation principles and practices. Manual M4, Sixth Edition.

21. Galal-Gorchev H, Ozolins G, Bonnefoy X (1993) Revision of the WHO guidelines for drinking water quality. Ann Ist Super Sanita 29: 335-345.

22. World Health Organization (WHO) (2011) Guidelines for Drinking Water Quality. (4 ${ }^{\text {th }}$ edn), WHO Press, Geneva, Switzerland.

23. (1994) Fluorides and oral health. Report of a WHO Expert Committee on Oral Health Status and Fluoride Use. World Health Organ Tech Rep Ser 846: 1-37.

24. Beltrán-Aguilar ED, Barker L, Sohn W, Wei L (2015) Water Intake by Outdoor Temperature Among Children Aged 1-10 Years: Implications for Community Water Fluoridation in the U.S. Public Health Rep 130: 362-371.

25. Murrey JJ, Rugg-Gunn AJ (1976) Fluoride in caries prevention. Water Fluoridation and Child Dental Health, Wright, Bristol, UK, 25.

26. World Bank (1994) From Scarcity to Security: Averting a Water Crisis in the Middle East and North Africa. The World Bank, Washington DC, USA.

27. WRI (World Resources Institute) (1996) World Resources, a guide to the global environment - the urban environment. WRI/UNEP/UNDP/WB, Oxford University Press.

28. Kebede A, Retta N, Abuye C, Whiting SJ, Kassaw M, et al. (2016) Dietary Fluoride Intake and Associated Skeletal and Detal Fluorosis in School Age Children in Rural Ethiopian Rift Valley. Int J Environ Res Public Health 13: 756.
29. Voinovic J, Tatic E, Andelic P, Pintaric J (1990) Preventive program in dentistry. Scientific book, Beograd (in Srbian).

30. Hydrometeorological Service of the Republic Macedonia.

31. Mladenovic B, Donev D, Spasovski M (2009) Gender analysis of sexual behaviour of senior high-school students in Skopje, R. Macedonia - cross-sectional study. Prilozi 30: 179-190.

32. Velkoski S (2010) Hydrogeology and hydrogeological characteristics of the country. Institute of Geobiology, archeology, groundwater and ecology (IGAPE), Skopje, (in Macedonian).

33. Centeno J, Finkelman RB, Selinus O (2016) Medical Geology: Impacts of the Natural Environment in Public Health. Geosciences 6: 8 .

34. Ambarkova V, Sijakova-Ivanova T, Zabokova-Bilbilova E (2012) Preliminary investigations of fluorine content in the three main lakes in the Republic of Macedonia. Geologica Macedonica 26: 81-86.

35. Commission staff working document (2016) The former Yugoslav Republic of Macedonia 2016 Report. Accompanying the document Communication from the Commission to the European Parliament, the Council, the European Economic and Social Committee and the Committee of the Regions. 2016 Communication on EU Enlargement Policy, Brussels, 9.11.2016, SWD(2016) 362 final.

36. Law on Environment (2005) No. 53/05. Official Gazette of the Republic of Macedonia.

37. Law on Waters No. (4/98, 19/00, 87/08, 6/09, 161/09, $83 / 10,51 / 11,44 / 12,23 / 13,163 / 13$ ) of the Official Gazette of the Republic of Macedonia.

38. Law on Water Management Enterprises (2003) No. 85/03 of the Official Gazette of the Republic of Macedonia.

39. Law on Drinking Water Supply and Urban Wastewater Drainage (2004) No. 68/04 of the Official Gazette of the Republic of Macedonia.

40. Abouleish MYZ (2016) Evaluation of fluoride levels in bottled water and their contribution to health and teeth problems in the United Arab Emirates. Saudi Dent J 28: 194-202.

41. Regulation for a special request for the safety of natural mineral water (2006) (No 32/06 of the Offical Gazette of the Republic of Macedonia).

42. Ambarkova V (2013) Content of the fluorine in the bottled water in the Republic of Macedonia. Vox Medici XXII: 281-284.

43. Wasana HM, Perera GD, Gunawardena PS, Fernando PS, Bandara J (2017) WHO water quality standards vs synergic effect(s) of fluoride, heavy metals and hardness in drinking water on kidney tissues. Sci Rep 7: 42516. 